\title{
BEHAVIOR OF (n AND p) InP IN LIQUID AMMONIA IN PRESENCE OF AMIDE IONS AND AMMONIUM IONS
}

\author{
A. ETCHEBERRY, M. HERLEM, C. MATHIEU, M. BERHIL and J.-L. SCULFORT \\ Laboratoire d'Electrochimie Interfaciale du CNRS, 1 place Aristide Briand, F-92195 Meudon cedex, \\ France
}

\begin{abstract}
The interface formation of the junction ( $n$ and $p$ ) InP/liquid ammonia is examined in terms of acid base equilibrium of adsorbed species (issued from the solvent) from impedance measurements recorded in basic (potassium amide) and acidic (ammonium bromide) solutions.
\end{abstract}

\section{1.- Introduction}

The behavior of III-V semiconductors is of interest because in water their flat band potential response $\mathrm{V}_{\mathrm{FB}}(\mathrm{pH})$ is Nernstian. This is the case of InP for $\mathrm{pH}$ superior to 3 [1]. This behavior is due to a very particular structure of the interface between water and the material. It is known that this material is covered with a thin oxide iilm of less than 10 Angstroms thickness after a mechano-chemical etching by a bromine solution (2\%) in methanol leading to a reliable (photo)electrochemical behavior.

In water there is an acid-base equilibrium at InP surface with $\mathrm{H}^{+}$or $\mathrm{HO}^{-}$ species leading to a change of the adsorbed species charge $\Delta Q$ at the interface and consequently a potential variation:

$$
\begin{aligned}
& \Delta \mathrm{V}_{\mathrm{FB}}=1 / \mathrm{C}_{\mathrm{H}} \times \Delta \mathrm{Q} \text { (with } \mathrm{C}_{\mathrm{H}}=\text { Helmholtz capacity) } \\
& \text { material }\left.\right|_{\mathrm{H}^{+}} ^{\mathrm{H}} \text { (water), material }\left.\right|_{\mathrm{HO}^{-}} ^{\mathrm{H}} \text { (water) }
\end{aligned}
$$

This potential shift of the band edges is reversible and equal to $60 \mathrm{mV} /$ unit of $\mathrm{pH}$ at room temperature. Such a structure and the reversibility of its behavior is the fundamental problem for the junction description. Consequently the characterization of a junction SC/electrolyte needs the knowledge of its interface behavior toward specific species issued from the solvent $[2]$.

Since water is a very particular solvent which can strongly interact with the material not only by acid-base reactions but also by redox reactions leading to the formation of oxides whose the rôle is not well elucidated, we used 
liquid ammonia (which looks like water $|3|$ and which can be obtained water free) to avoid any further evolution of the interface which could be assigned to water reactions with it. In this solvent we have examined the behavior of InP toward acidic ions and basic ions on one hand and the reversibility of the phenomena on the other hand.

In liquid ammonia the solvated protons are merely ammonium ions, the basic species equivalent to hydroxyle ions are amide ions and play the same róle as $\mathrm{H}_{3} \mathrm{O}^{+}$or $\mathrm{HO}^{-}$. More exactly ion pairs rather than ions exist in ammonia : separated ion pairs for protons and contact ion pairs for amide ions. Notice that the explored ranges of $\mathrm{pH}$ are small, roughly 3 units as well as in acidic media or basic media, because convenient acid-base buffers do not exist in liquid ammonia.

\section{2. - Experimental}

The electrochemical cell, the distillation device for ammonia and the give used for preparing electrodes have been already described [2]. KBr (PROLABO for IR spectro) was the supporting electrolyte $(0.1 \mathrm{M})$. Acidic solutions were obtained by additions of $\mathrm{NH}_{4} \mathrm{Br}$ (PROLABO Normatom). Basic solutions were prepared by additions of potassium (PROLABO) and complete discoloration of the obtained solutions. All the potentials are reported versus the $\mathrm{Ag} / \mathrm{AgNO}_{3}(5 \times$ $\left.10^{-3} \mathrm{M}\right)$ reference electrode (denoted SRE). The runs have been performed at 223K . Electrode areas were roughly $4 \mathrm{~mm}^{2}$. ( $\mathrm{n}$ and $\mathrm{p}$ ) InP was provided from MCP Electronics Ltd. The doping concentration was about $10^{18} \mathrm{~cm}^{-3}$.

Two electrodes of the same material were placed at the same time in the cell and during additions of potassium for preparing $\mathrm{KNH}_{2}$ solutions they were emerged from the liquid until it was not colored. The electrodes were in contact with amide solutions only during the recording of $\mathrm{C}(\mathrm{V})$ or $\mathrm{I}(\mathrm{V})$ curves for less than 10 minutes.

\section{3.- Results}

The current-voltage curves in liquid ammonia are represented on fig. 1 for different $\mathrm{pH}$. Notice that for solvated electron solutions there is an ohmic contact between the SC electrode and the solvent. This ohmic contact is also observed during the plotting of voltammograms for very negative bias in neutral and basic media. Such a behavior was already observed [2].

The impedance-voltage curves (see $f$ ig. 1) are always perfect parabolas without hysteresis whatever the composition of the solutions may be and whatever the electrode treatment may be, thus flat band potentials $v_{F B}$ lobtained by extrapolation at zero from $1 / \mathrm{C}^{2}(V)$ curves) are easy to deduce. The plotting of $V_{F B}$ vs $\log \left(H^{+}\right)$or $\log \left(K_{\text {added }}\right)$ gives the curves collected $f i g$. 2 . One can see a "classical" acid-base jump of potential on the $\mathrm{V}_{\mathrm{FB}}=f\left[\log \left(\mathrm{K}_{\text {added }}\right)\right]$ curve for InP electrodes which were preserved of any contact with potassium solutions during their discoloration. This jump can be easily correlated with the presence of water as we will see later.

For $n-I n P$ and $p-I n P$ the curves $v_{B P}=f\left[\log \left(\mathrm{NH}_{4}{ }^{+}\right)\right]$are straight lines (with a potential shift of $1.4 \mathrm{~V}$ )in the whole explored $\mathrm{pH}$ range while $\mathrm{V}=$ 
$f\left[\log \left(K_{\text {added }}\right)\right]$ or $f\left[\log \left(\mathrm{NH}_{2}{ }^{-}\right)\right]$are straight lines too (with a potential shift of $1.4 \mathrm{~V})$ from the end of the titration of water. Notice that the slopes of these lines are closed to $0.044 \mathrm{~V} /$ decade which is equal to RT/F at $223 \mathrm{~K}$. This means that these electrodes are good probes for the measurement of $\mathrm{pH}$ in ammonia solutions.

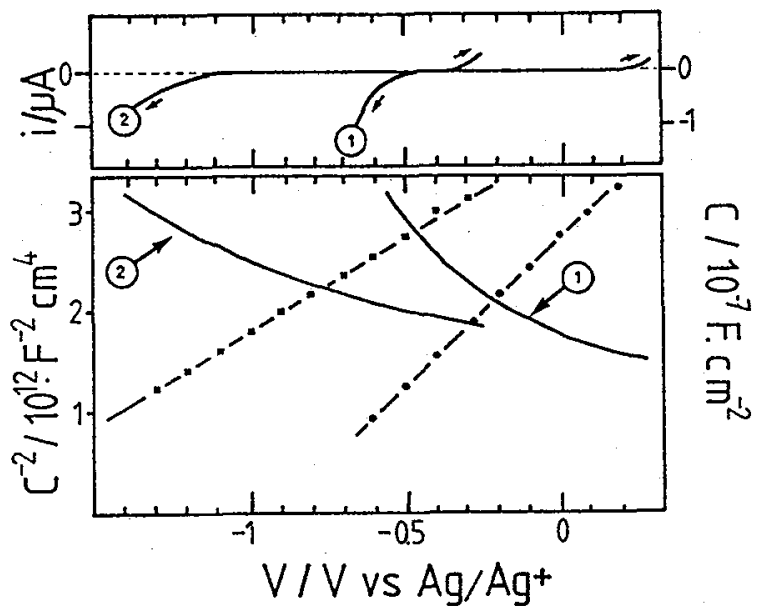

Fig.1.- n-InP electrode : current-voltage and capacity-voltage curves in acidic medium, $\left[\mathrm{NH}_{4}^{+}\right]=2 \times 10^{-2} \mathrm{M}$ (curves 1 ) and in basic medium $\left[K_{\text {added }}\right]=2 \times 10^{-2} \mathrm{M}$.
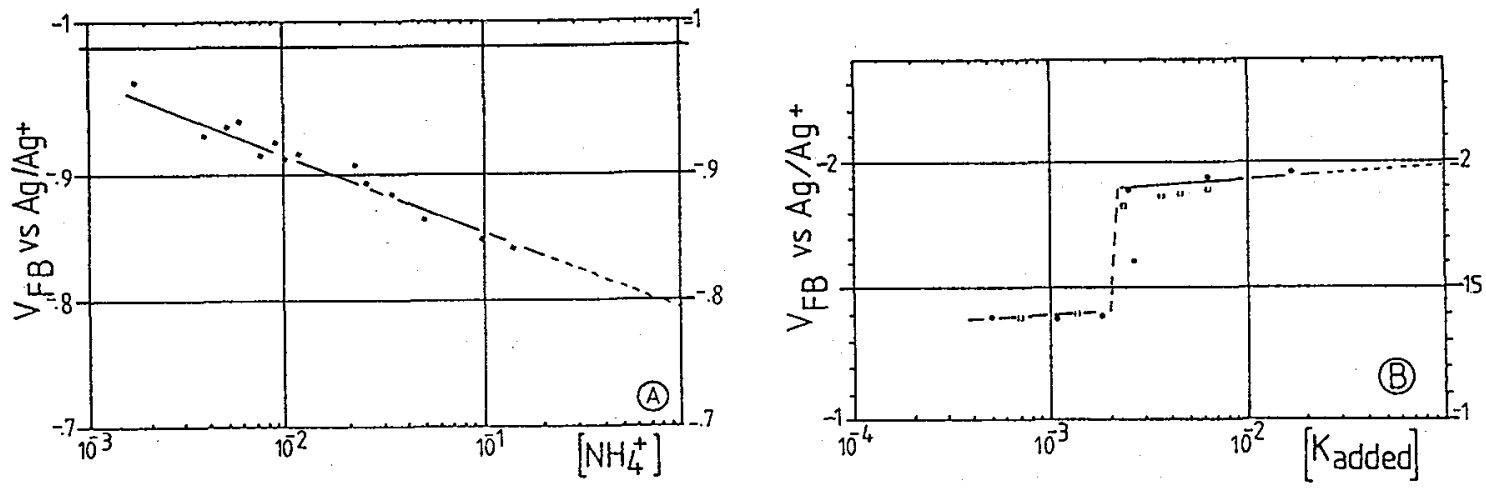

Fig.2.- $n$-InP electrode : $V_{F B}$ vs $\left[\mathrm{NH}_{4} \mathrm{Br}\right\rceil$ and $\mathrm{v}_{\mathrm{FB}}$ vs $\left\lceil\mathrm{K}_{\text {added }}\right]$.

From this result it was intersting to verify if the good value of the $\mathrm{pK}_{i}$ of liquid $\mathrm{NH}_{3}$ could be deduced. For $n$-InP the difference between both extrapolated $\mathrm{V}_{\mathrm{FB}}$ values for $\left(\mathrm{NH}_{4}{ }^{+}\right)=1 \mathrm{M}$ and for $\left(\mathrm{NH}_{2}{ }^{-}\right)=1 \mathrm{M}$ is equal to: 


$$
\Delta v_{F B}=-0.8 v-(-2.05) v=1.25 \mathrm{v}( \pm 0.030 \mathrm{v})
$$

which corresponds to :

$$
1.25 / 0.044=28,5 \text { units of } \mathrm{pH} \text {. }
$$

This value is close to the $\mathrm{pK}_{i}$ of ammonia at this temperature [3].

Since the $n$-InP electrode is a probe of $\mathrm{pH}$ one can also deduce the $\mathrm{pk}_{\mathrm{a}}$ of water from the curve $\mathrm{V}_{\mathrm{FB}}$ vs $\log \left(\mathrm{K}_{\text {added }}\right) \cdot \mathrm{H}_{2} \mathrm{O}$ is an impurity always present which becomes from moisture contained in the supporting electrolyte and adsorbed water on the glass in spite of vacuum pumping. It is not easy to detect on smooth platinum electrode. One can see that the potential drop corresponds to the titration of $\mathrm{H}_{2} \mathrm{O}$. In our runs its concentration is always close to some $10^{-3} \mathrm{M}$. From $\mathrm{v}_{\mathrm{FB}}(1 / 2)$ for half titration one can deduce the $\mathrm{pK}$ value of water :

$$
\mathrm{pK}_{\mathrm{a}}\left(\mathrm{H}_{2} \mathrm{O}\right)=\left\{\mathrm{V}_{\mathrm{FB}}\left[\text { extrapolated for }\left(\mathrm{NH}_{4}{ }^{+}\right)=1\right]-\mathrm{V}_{\mathrm{FB}}(1 / 2)\right\} / \mathrm{RT} / \mathrm{F}
$$

$=\{-0.8-(-1.40\}\} / 0.044 \simeq 14$ which is close to the literature value.

\section{Reversibility of the phenomena :}

If additions of protons are done for acidifying the potassium amide solutions one can see that there is a reversibility but the deduced $V_{F B}$ are not strictly the same as those obtained formerly in acidic media. In some cases (may be due to differences in contact times of the electrodes with potassium amide solutions) the variations are not Nernstian.

After an addition of ammonium ions for obtaining an acidic solution the n-InP electrode, by example, seems to have a Nernstian response. $V_{F B}$ vs $\left[\log \left(\mathrm{NH}_{4}^{+}\right)\right]$ is close to a straight line with a slope close to $0.044 \mathrm{mV}$ but its extrapolation to $\left(\mathrm{NH}^{+}\right)=1 \mathrm{M}$ gives :

$$
\left.v_{\mathrm{FB}} \text { [extr. for }\left(\mathrm{NH}_{4}^{+}\right)=1 \mathrm{M}\right]=-0.85 \mathrm{~V} \pm 0.05 \mathrm{~V} \text {. }
$$

This value is slightly different from those obtained with an electrode protected from the contact of solvated electrons (average $0.8 \mathrm{~V}$, see before).

4.- Discussion

Since $\Delta V_{F B}$ from basic to acidic media corresponds to :

$$
(0.044 \mathrm{~V}) \times \mathrm{pK}_{\mathrm{i}} \text { (of liquid ammonia) at } 223 \mathrm{~K}
$$

one can conclude there is an acid base equilibrium onto the material surface which means a strong interaction between $\mathrm{NH}_{4}^{+}$or $\mathrm{NH}_{2}^{-}$ions and the interface. $S j m i l a r l \underline{y}$ in water, there is a stong interaction between InP surface and $\mathrm{H}^{+}$or $\mathrm{HO}^{-}$ions $[1]$. 
This interaction is reversible as shown by the behavior of the electrode in water after a stay in amide solutions and differs from the interaction between $\mathrm{HS}^{-}$ions and InP surface [4] which is irreversible after some minutes : bonding between sulïur and indium atoms and concomitant modification of the material stoichiometry due to $\mathrm{P}$ atoms expulsion (phosphine evolvement). In this last case the behavior of InP electrodes is definitely not Nernstian in water.

This strong interaction between solvated protons and ammonia can be verified on InP for cathodic bias : the reduction of solvated $\mathrm{H}^{+}$leads to the formation of metallic indium like in water $[5]$.

In acidic media additions of protons are tied to concomitant additions of water and "a priori" the influence of water could not be completely rejected. But the finding of the $\mathrm{pk}_{i}$ value of ammonia seems indicate that water adsorption is not implicated. For neutral and acidic media this can be explained by the strong interaction of water and ammonia at low temperature while for basic media this can be explained by the complete transformation of $\mathrm{H}_{2} \mathrm{O}$ into hOH. Although $\mathrm{H}_{2} \mathrm{O}$ is a weak acid - $\mathrm{pk}_{\mathrm{a}}=16[6]-$ it reacts almost completely onto $\mathrm{KNH}_{2}$ :

$$
\mathrm{H}_{2} \mathrm{O}+\mathrm{KNH}_{2}=\mathrm{KOH}+\mathrm{NH}_{3}
$$

the $\mathrm{pK}$ of the reaction between equal to : $\mathrm{pK}_{\mathrm{a}}-\mathrm{pK}_{\mathrm{i}}=16-30=-14$.

The behavior of p-type InP leads to the same $V_{F B}$ shifts and the valence band edge potentials of this material vs the $\mathrm{pH}$ are shifted of $1.4 \mathrm{~V}$ vs SRE from the conduction band edge potentials. One can notice that $1.4 \mathrm{eV}$ is precisely the gap energy value of InP what means the parallelism between the behaviors of InP/water junction and of InP/ammonia junction is entire. This is also supported by the fact that the validity of the anion rule is confirmed (see fig. 3) [7].

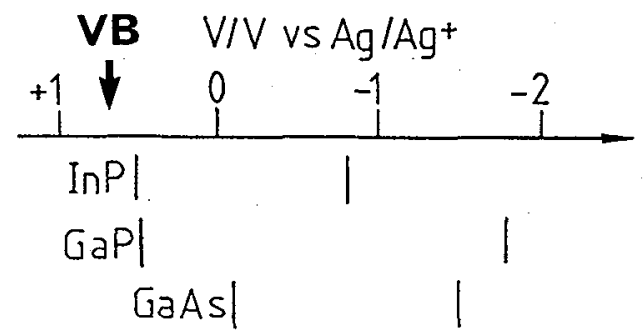

Fig.3.- Energy diagram of InP, GaP and GaAs in acidic medium $\left[\mathrm{NH}_{4}^{+}\right] \simeq 10^{-1} \mathrm{M}$.

\section{Conclusion}

Like in water, species issued from ammonia can give strong acid base interactions with the InP interface as it is pointed out from the electrochemical behavior of $p$ - and $n$-type InP. 
In basic media were $\mathrm{H}_{2} \mathrm{O}$ molecules do not exist the interactions with the solvent are completely different from those existing in water and the fact that the behavior is still Nernstian is important : the determination of the $\mathrm{pK}_{\mathrm{i}}$ value of liquid amonia is close to theoretical value.

These interactions are not yet elucidated since for ammonium additions the "normal" behavior in acidic media is not fully restored. The role of the native oxide layer remains to be elucidated and it is clear that such a study in liquid ammonia will be of interest for solving the problem of the InP interface formation in water itself.

\section{References}

/1/ Etcheberry,A, thèse de Doctorat d'Etat, Iniversity of Paris VI, 1985,

/2/ Guyomard, D, Mathieu, C, and Her lem, M, J. Electroanal.Chem., 246 (1988) 29,

/3/ Charlot, G, and Trémillon, B, in "Les réactions Chimiques dans les solvants et les sels fondus", Gauthier-Villars, Paris 1963,

/4/ Etcheberry,A, Herlem, M, Mathieu,C, and Sculfort,J-L, "Journées d'Electrochimie", F-Montpellier, June 1989,

/5/ Moreau, T, Etcheberry, A, Herlem, M, Nicolau,Y-F, and Delamar, M, C.R. Acad. Sc. Paris, 308, Série II (1989) 275 ,

/6/ Herlem,M, and Thiébault, A, Bul. Soc. Chim. Fr. (1969) 383 and (1971) 719,

/T/ Etcheberry, A, Herlem, M, Mathieu,C, and Sculfort,J-L, J. Electroanal. Chen., to be published. 